\title{
MOTIVATING SCHOOLGIRLS TO LEARN DISCIPLINES OF INFORMATION TECHNOLOGIES AND PHYSICS
}

\author{
Aiste Urboniene \\ Vilnius University, Kaunas Faculty of Humanities, \\ Department of Philosophy and Culture Studies, Lithuania
}

\begin{abstract}
Sector of technological and physical sciences is exceptionally male professional area. It is rather difficult to motivate girls already in the school for career in this field. Professional gender stereotypes are one of the main reasons that impact attitudes towards girls in this male area. In this young age both parents and teachers play an important role as well as dominating images in media, forming aspirations concerning professional career. Thus, the school environment is particularly significant as motivating or demotivating girls to select this pathway of their professional career.

This paper is aimed to identify factors significant for development of professional motivation for technological and physical sciences among schoolgirls in Lithuanian schools. The sample consisted of 1398 schoolchildren (58 \% females and $42 \%$ males) from 33 Lithuanian schools. The average age of the schoolchildren was 16-17 years. The study was financed by Ministry of Education and Science of the Republic of Lithuania.

The results of the empirical analysis indicated that boys expressed stronger professional motivation and showed higher interest in IT and Physics practicing the related activities on their free time, whereas girls expressed lower evaluation of their abilities to learn IT and Physics and more follow gender stereotypes.
\end{abstract}

Keywords: technological and physical sciences, gender stereotypes, professional motivation.

\section{Introduction}

The motives of choosing a profession begin to form while learning at school, and the appropriateness of this decision influences the personal welfare of a young person. In the senior classes of Lithuanian secondary schools, pupils are choosing subjects, which make the basis of their future carrier. The overall profile education has been introduced in Lithuanian secondary schools in 2000, but later on, while reforming this system, it was changed to the profile education model when pupils of $11-12^{\text {th }}$ grade independently choose $40 \%$ of the taught subjects in the $11^{\text {th }}$ grade. The choice of the subjects and their teaching level usually influences the final examinations. The created practice of choosing the dominating subjects and their levels was aimed to correspond to the future carrier aims of the pupils (Gesevičienè, Mazètis, 2014).

The unpopularity of natural science as a choice in the secondary school or later on in higher education institutions is an important issue in Lithuania. For 
example, last year, only $15 \%$ of applicants to the Lithuanian universities chose to study programmes of technological sciences (LAMA BPO, 2015). According to the number of students that are studying computer sciences, Lithuania is second from the end in the whole EU. Mathematics is the only subject from the sphere of the accurate sciences that is compulsory for all the pupils; whereas, IT and physics are usually chosen by a small number of pupils (Gesevičiené, Mazètis, 2014). However, there has been observed a lack of these field specialists in the labour market (Gesevičienè, Mazètis, 2015). Thus, the popularity of technological and physical sciences is very important, because in the future, these specialists will be lacked even more. This is quite relevant, especially when discussing the gender differences. European economies require STEM skilled people, yet compared with males, females demonstrate a tendency to reject some STEM study and STEM careers.

Thus, the question arises whether females and male pupils are free to choose such subjects of interest that they are attracted to, or gender stereotypes do appear in this area as well. When looking at the existing but not always effectively functioning profile orientation system in schools (Indrašienè et al., 2006), based on the assumption that there exist traditional gender stereotypes in the media and popular culture, it is possible to believe that the formation of professional motivation for physical and technological sciences, especially for females, is overburdened with many aspects, in comparison to males. Thus, it is important to reveal the motives that encourage schoolgirls in secondary school to be interested in and choose the teaching subjects related to physical and technological sciences that are necessary when applying to the higher education institutions. In other words, the basis of professional interest for the mentioned subjects that encourage relating professional carrier with such science fields should begin to form in the secondary school.

Thus, this paper aims to identify the factors that are significant for the development of professional motivation for technological and physical sciences among the schoolgirls in Lithuanian schools.

\section{Concept of professional motivation}

Professional motivation is defined as a dynamic hierarchic system of motives, conditioned by interaction of personality and socio-cultural factors, determining choice of professional activity and the corresponding behavioural strategy in seeking acquisition of the selected profession and self- realisation in the labour market (Urboniene, 2009). Professional motivation is attempted to be defined as a system, uniting different needs of an individual, and which is influenced by individual's relation with personal self and with socio-cultural environment. 
There are two kind of factors that influence development of professional motivation (Elofsson, 1998) (see Figure 1).

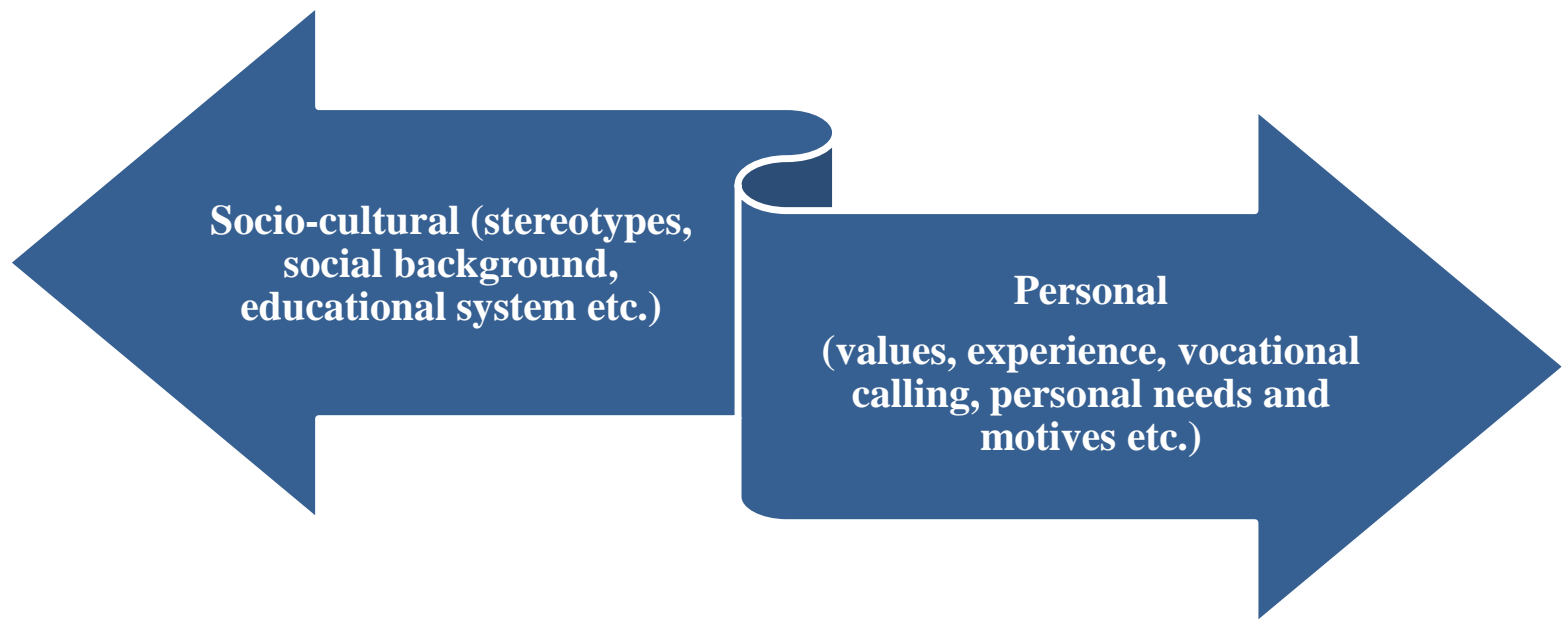

Figure 1 Factors influencing development of professional motivation

When discussing the sociocultural aspects and their influence on professional motivation, it is clear that different systems: ideological, educational, labour market, determine the personal attitudes towards particular professional activities. Among the sociocultural aspects, gender stereotypes are very important, especially those related to professions. It has been determined that stereotypical evaluation of masculinity and femininity influences gender segregation in various professions and becomes a serious obstacle for women seeking professional carrier in the field of physical and technological sciences (Michie, Nelson, 2006; Darmody, Smyth, 2005). Masculinity is historically related not only with the rationality and physical strength, but as well with the critical thinking, independence, self-confidence, aggression, objectivity, activeness, materiality, ambitiousness (Wood, 2003; Connell, 2006). Whereas, the stereotypical concept of femininity embodies such characteristics that contradict to the masculinity, i.e., tendency to care, concern, depend on others, attractiveness, communication, subjectivity, sensitiveness, caution, empathy, intuition, etc. These categories that reveal stereotypical femininity influences the negative women evaluation of their suitability for physical and technological sciences.

Of course, the cultural basis as well as such social aspects as social class or family determine the pupils' choice of carrier. No less influential for the development of professional motivation are the aspects of the educational process organisation: usefulness of knowledge, integration of theory and practice, selection opportunities, the role of teacher, psycho-social climate, positive interaction between the teacher and student (Carlsson, 2001). 
What concerns personal aspects, the values play an important role in the formation and development process of professional motivation. According to Quigley and Tymon (2006), such internal motives as meaningfulness, competence, choice, and progress are especially important when choosing a carrier. This group of motives is related to self-realisation, worldviews, ideals, etc.

Among the personal factors, the evaluation of the own professional suitability is crucial for the development of professional motivation. It can be defined as the evaluation of adequate qualities and necessary competencies to satisfactory function in a chosen professional field. In this context, the acquired personal experience is meaningful and can strengthen or weaken the professional self-evaluation in a particular professional area. Thus, the interaction of these personal and socio-cultural factors, influencing the professional choice of an individual, is significant for the development of professional motivation.

The researches have shown that young persons are encouraged to choose studies of physical and technological sciences by various internal and external motives that reveal the need for self-realisation and material gain (Baytiyeh, Naja, 2010). According to Gesevičienè and Mazètis (2015), the choice of pupils to learn accurate sciences is influenced by the internal (personal aims, competences, wishes, etc.) and external (social, learning environment, educational, etc.) aspects, to which are ascribed the aspects that have been identified during the research, i.e., opinion of family members and relatives, information about the higher education institutions (their websites, advertisements, meetings with representatives of higher education institutions, open door days, etc.), acquaintances that represent different professions and especially the competence of the subject teacher. All this determines not only the success of the learning, but as well the attitude towards the teaching subject. Thus, positive attitudes encourage to get interested in the taught subject or to relate the acquired knowledge and skills with the future professional activities.

To sum up, it should be stressed that the choosing/not choosing the physical and IT subjects by the schoolgirls in Lithuanian secondary schools is determined by the sociocultural aspects, because they encounter with unfavourable attitudes formed by the gender stereotypes, according to which male are more suitable for the mentioned professional areas.

\section{Methodology}

Lithuanian Education and Science Ministry funded study "Analysis of the state of Lithuanian education: Lithuanian female pupils and students in exact and technological sciences" was conducted in 2007-2008 m. (Novelskaite, 
Puvaneckienè, Urbonienè, 2011; Urbonienè, 2011). During its implementation, a questionnaire of final class pupils from Lithuanian secondary schools and gymnasiums was conducted in order to determine the characteristics of schoolgirls' attitude towards physical and technological sciences and the perception of their place in the activities related to these areas of science.

At the beginning of the research, there was raised a hypothetical assumption that the pupils are influenced to choose or not to choose physical or IT subjects by three reasons:

a) Image of physical and technological sciences (as well as the image of a woman);

b) Interest in physical and technological sciences;

c) Stereotypes prevailing in the society about physical and technological sciences

It has been determined to conduct the research among the pre-senior class pupils $\left(11^{\text {th }}\right.$ grade of the secondary school and $3^{\text {rd }}$ grade of gymnasium). The questionnaire was conducted in 33 educational institutions (19 schools in cities and 14 in villages). The data gathering was implemented at Lithuanian secondary schools and gymnasiums in 2008.

The pupils questionnaire was carried out in two ways: by conducting a direct questionnaire (in 25 schools) and by completing the questionnaire via email (8 schools). In total, 1398 pupils completed the questionnaire, from which more than half were females. During the survey, the analysis of gathered data was completed by using SPSS 13.0 software package for the closed questions (quantitative data) analysis and Excel package for the open questions (qualitative material) analysis.

During the research, the following principles of ethics were maintained: responsibility of the researcher to render information about the purpose of the analysis, voluntarism of the persons involved in the research, fairness and the anonymity of the research.

In order to determine the motives that encouraged not choosing physics and IT subjects, female and male respondents were asked to answer the following question: "Some of the above listed teaching subjects are compulsory, and some could be chosen. What and how strongly influenced your decision not to choose some of them?". As an answer pupils had to write the chosen value in 5 point scale. By doing this, there was provided a possibility to express their opinion in free writing. The received statements were grouped into meaningful groups according to the reasons that determined not to choose the mentioned subjects. After the data were systematised, four categories stood out: lack of professional interest, poor professional motivation, external influences for choices and limitations. The analysis of answers to this question helped to identify the 
aspects that in some way encouraged or discouraged the formation of possibilities of professional motivation.

Moreover, the respondents answered the open question: "How do you think, what reasons determine that you are successful or not successful in learning IT or physics?". First, the obtained qualitative data were divided into the reasons that determine successful and unsuccessful learning. Later on, the data were systematised by highlighting these internal aspects: professional motivation (professional interest, applicability of knowledge in practice), efficiency (abilities, qualities, knowledge, personal experience) and attitude (additional activities, put efforts). Among the external aspects, there has been identified such: educational aspects (learning methods, the specificity of the subject), the influence of the teacher and family members.

The reasons that encouraged unsuccessful learning were divided into similar groups. Among the internal reasons, there was particularly highlighted poor professional motivation, low efficiency and attitudes (stereotypes). Among the external aspects, educational aspects and teacher's influence were relevant as well.

The third question, which answers were analysed, was "Where and how do you like or would like to learn the listed subjects?" It aimed to determine methods and environments that would motivate pupils to learn. When answering this question, it was necessary to evaluate 12 statements by writing the appropriate value in five-point scale. These data were classified into meaningful groups by identifying the most attractive learning environments and methods.

\section{Results}

First of all, it was aimed to determine the reasons that encouraged not choosing IT and physics subjects. It has been found out that the decisions of male and female pupils were determined by the motives oriented towards professional career planning, and the schoolgirls and schoolboys stressed that they do not relate these subjects with personal goals. At the same time, there has been highlighted the lack of professional interest in the mentioned subjects. The other group of aspects, personal aspects, encompass such aspects as confidence in personal abilities or thinking that there is a lack of skills necessary for successful learning of the subject. Finally, a group of the aspects that was slightly less influential on the pupils' choice was their closest environments, i.e., the influence of family members, male and female subject teachers, friends.

Even though the respondents noticed that the most important reasons for not choosing such subjects were the fact that they were not planning to relate them with their future professions, it should be stressed that this was more 
relevant among schoolgirls (e.g. for comparison, the average grades of physics was 4,2 for schoolgirls and 2,9 for schoolboys).

The other tendency is the lack of professional interest, which was expressed more strongly by schoolgirls only for some subjects (physics, IT), in comparison to the schoolboys (e.g. the average grade of physics is 3,7 for schoolgirls and 2,7 for schoolboys, whereas in the case of IT, the average grade was 2,9 for schoolgirls and 2,2 for schoolboys). It has as well been revealed that females evaluate their abilities to learn physics and IT more unfavourable in comparison to males. A similar attitude has been observed in the presupposition of females that they would be unsuccessful in the mentioned subject (especially physics).

When evaluating the influence of persons that are important for the teenagers (family members, subject teachers and friends) on the choice of subjects, it has been revealed that the most important for the females is the influence of the subject teacher, especially in the case of physics. Whereas, for the males, the most important was the influence of friends, even though the subject teacher's behaviour with pupils was relevant as well.

The qualitative data confirmed the influence of the mentioned aspects on the pupils' choices not to learn IT or physics. Both male and female pupils named educational aspects as one of the most important reasons for not choosing the subject. It has been proved that such disadvantages as unsuccessful teaching load distribution, poor planning of the lesson or incompetent teachers have significant influence for not choosing the mentioned subjects. The influence of friends has been mentioned (e.g. "it is not popular in our school" or "my friends advised me not to choose this subject"). The family was influential for the respondents as well.

The researched aimed to determine what aspects influences successful learning of IT and physics. Thus, it has been proved that the successful learning of IT subject was determined by the influence of relatives (e.g. "I am successful because my mother is a programmer") and the already obtained knowledge (e.g. "good basic knowledge"). What concerns the gender differences, females more frequently than males stressed teacher's pedagogical competence (e.g. "teacher that has acquired a sufficient amount of knowledge, is eager to help, explain and work"), need for IT in the society (e.g. "this subject is very important in the contemporary society, so I am trying to learn as much as possible"), applicability of knowledge in practice (e.g. "practical application of knowledge"), skills (e.g. "it depends on where parents and grandparents were successful") as well as abilities such as accuracy. Whereas the unsuccessful IT learning is determined by the professional incompetence of teachers, complexity of the subject and external reasons, for example, missed lessons. Females as well mentioned the lack of professional interest (e.g. "I will not need it, I am too 
lazy to learn"), lack of skills (e.g. "I do not have the skills"), stereotypes (e.g. "technology + girl = catastrophe").

Whereas, in the case of unsuccessful IT learning, males stressed personal experience: most of them stated that they are playing computer games from childhood and have the skills to use a computer. In the case of failure, they mentioned only the disadvantages of teaching timetable.

Continuing to analyse the reasons influencing successful learning of physics, it is interesting that male and female pupils highlighted the already acquired knowledge, professional skills, influence of relatives and the applicability of knowledge in practice. Most males stressed the put efforts and additional interest in the subject. The females highlighted such reasons of successful learning of physics as teacher's competence and teaching methods that are suitable for them, e.g., laboratory work. The female respondents based the unsuccessful learning of physics on limitations, e.g., tiredness; they as well mentioned the lack of professional interest and professional skills, the complexity of the taught subjects and stereotypical attitude (e.g. "female brain is not working well; I usually do not understand physics"). Whereas, the males identified the lack of personal interest (e.g. "laziness") and teacher's incompetence (e.g. "incorrect evaluation, too high expectations") as the main reason of unsuccessful learning.

In conclusion, it could be stated that the main reasons why both female and male pupils were successful in the mentioned subjects are professional interest, efficiency or acquired skills, personal features and knowledge, put efforts, organisation of the learning process and the help of teachers and relatives in learning.

Finally, the respondents were asked about the most attractive learning methods and environments in order to disclose their influence on the formation of professional motivation. The empirical data revealed that the attractive learning methods are related to media and IT. It has been proved as well that the discussion of topics related to physics and IT with teenagers is motivating. The respondents discuss the topics of the mentioned subjects with their friends and parents. Additional information is searched in books, encyclopaedias, reference books, internet, by participating in contests and Olympiads, and this is important in respect of professional motivation formation because it develops professional interest. However, pupils tend to participate in various after school activities less frequently.

All these answers revealed relevant differences between the answers of male and female pupils. Thus, the additional interest as an expression of professional interest was more strongly stressed in male evaluations. Especially prominent differences have been found in the cases of physical and informational technologies that are traditionally linked with science fields 
related to masculinity. For example, males mentioned a stronger interest in physics, because they usually deepen their knowledge by reading books and conducting physical experiments. The stronger male interest in IT was manifested by more frequent search for information on the internet and experimental activities.

The formation of professional motivation for physics and IT is encouraged by such learning method that has been identified as the most attractive by male and female pupils, i.e., experimentation. Males as well mentioned games and stressed the watching of TV shows and practical application of knowledge. Thus, male and female pupils prefer the practical application of knowledge and untraditional teaching methods, which require more flexibility and creativity of the subject teacher. What concerns the learning environments, when having an additional interest in one or the other subject, knowledge is acquired and deepened at home and school as well as by visiting parents' workplaces.

\section{Conclusions}

In conclusion, the identified aspects only partially revealed the assumptions of professional motivation formation in pupils' choice. As it has been found out, the schoolgirls encounter obstacles of professional motivation formation in the context of personal, social, educational and sociocultural aspects. They have difficulties in self-realisation in the fields of physical and technological sciences, because a negative evaluation of their professional suitability prevails in female attitudes that are primarily manifested in the presupposition that they will not be successful in the mentioned subjects. They as well lack interest and willingness to find out more about the subjects. When analysing the manifestation of sociocultural aspects, it is clear that the most important obstacle to the formation of female professional motivation is their surrounding environment and the aspects of the educational system as well as gender stereotypes that most probably influence family members and friends' attitudes that physical and technological sciences are not suitable for females.

Striving to develop motivation of girls the most important factors can be divided into four groups:

- $\quad$ Personal - professional interest, positive evaluation of the own ability to learn IT and Physics;

- Social - positive interactions with subjects teachers, parents' support, friends' approval;

- Educational - inspiring learning environment, innovative teaching and learning methods, good distribution of learning load, high competence of subject teachers, positive feedback from subject teachers etc.; 
- $\quad$ Sociocultural - role of gender stereotypes, societal need of particular knowledge field, practical application of knowledge.

At the moment the dominating stereotypes can hardly motivate girls to choose and learn technological and physical subjects and even plan the professional career in these fields. Thus, complex means should be implemented for changes in this area from changed values and attitudes of subject teachers to changed media role as presenting examples of good practices and breaking gender stereotypes.

\section{References}

Alvesson, M., \& Billing, Y. D. (1997). Understanding Gender and Organizations. London: SAGE Publications.

Baytiyeh, H., \& Naja, M. K. (2010). Students' enrollment in Engineering: Motivational factors. The International Journal of Engineering Education, 26 (5), 1192-1199. Retrieved January 9, 2016, from http://www.ijee.ie/previous.html

Carlsson, C. (2001). Ungdomars möte med yrkesutbildning. Stockholm: HLS Förlag.

Connell, R. W. (2006). The Big Picture. Masculinities in recent world history. In M. Arnot, \& M. Mac An Ghaill (Eds.), The Routledge Falmer Reader in Gender \& Education (pp. 101-114). London \& New York: Routledge.

Darmody, M., \& Smyth, E. (2005). Gender and Subject Choice. Take up of Technological Subjects in Second-Level Education. Dublin: The Liffley Press.

Elofsson, S. (1998). Student på Socialhögskolan. Rapport i socialt arbete, 87, Stockholm: Akademitryck AB.

Gesevičienè, V., \& Mazètis, E. (2014). Renkamès tiksliuosius mokslus? Lietuvos matematikos rinkinys, Lietuvos matematiku draugijos darbai, B, 55, 28-33. Retrieved from http://www.mii.lt/LMR/

Gesevičienè, V., \& Mazètis, E. (2015). Tiksliujų mokslų dalykų pasirinkimo bendrojo ugdymo mokykloje motyvai. Acta Paedagogica Vilnensia, 35, 9-21. doi: 10.15388/ActPaed.2015.35.9187

Indrašienė, V., Rimkevičienė, V., Gaigalienė, M., Railienė, A., \& Grinytė, L. (2006). Mokinių profesinis informavimas, konsultavimas ir orientavimas. ŠMM Švietimo būklès tyrimai. Retrieved December 5, http://www.smm.lt/svietimo_bukle/docs/tyrimai/prof_inf_ paskut_paskutiniausias.pdf

Lietuvos aukštujų mokyklų asociacija bendrajam prièmimui organizuoti (LAMA BPO). (2015). $2015 \mathrm{~m}$. bendrojo prièmimo i Lietuvos aukštąsias mokyklas rezultatai. Retrieved January 14, 2016, from http://www.lamabpo.lt/node/853

Michie, S., \& Nelson, D. L. (2006). Barriers women face in information technology careers: Self-efficacy, passion and gender biases. Women in Management Review, 21 (1), 10-27. doi: 10.1108/09649420610643385

Novelskaite, A., Puvaneckienė, G., \& Urbonienè, A. (2011). Empiriniai lyties aspekto fizinių ir technologijos mokslų srityse tyrimai. Metodologiniai Lietuvos bendrojo lavinimo ir aukštosiose mokyklose bei mokslo organizacijose atliktu studijų ypatumai. In A. Novelskaite, \& G. Puvaneckienė (Eds.), Moteris fiziniuose ir technologijos moksluose: mokine, studenté, mokslininkè (pp. 25-59). Vilnius: Vilniaus universiteto leidykla. 
Quigley, N. R., \& Tymon, W. G. (2006). Toward an integrated model of intrinsic motivation and career self-management. Career Development International, 11 (6), 522-543.doi: $10.1108 / 13620430610692935$

Urbonienè, A. (2009). Factors Motivating Young Women for the Professional Career in the Field of Technological and Physical Sciences. Transformations in Business \& Economics, 8, 3 (18), 164-174.

Urbonienè, A. (2011). Mokinių profesinès motyvacijos formavimosi prielaidos fiziniu ir technologijos mokslų srityse lyties aspektu. In A. Novelskaite, \& G. Puvaneckienè (Eds.), Moteris fiziniuose ir technologijos moksluose: mokine, studente, mokslininke (pp. 60-76). Vilnius: Vilniaus universiteto leidykla.

Wood, J. T. (2003). Gendered Lives: communication, gender, and culture. Belmont: Thomson, Wadsworth. 